\title{
Co-Infection of Mycoplasma hyopneumoniae and other swine pathogens
}

\author{
Ke $\mathrm{Lu}^{1}$, Chenyu Wang ${ }^{1}$, Jinqi Shu ${ }^{1}$, Enoch Obeng ${ }^{1}$, Yuehong Wu ${ }^{1}$, Jian Chen ${ }^{1}$, Jianhong \\ $\mathrm{Shu}^{1}$, and Yulong $\mathrm{He}^{1}$ \\ ${ }^{1}$ Zhejiang Sci-Tech University
}

May 18, 2020

\begin{abstract}
Mycoplasma hyopneumoniae (M. hyopneumoniae, Mhp) is an etiological agent that causes mycoplasma pneumonia of swine (MPS), this is a chronic respiratory disease present in every major swine-producing country worldwide. It is well elucidated, Mhp infections may downregulate the host immune system and enhance the infection and replication of other pathogens. However, the mechanisms of interaction between Mhp and other pathogens is still missing. Though, additional studies have reported that several cofactors such as bacteria, vaccination failure, stress or crowing and other swine viruses in combination with Mhp, lead to MPS. Aside these cofactors, the co-infection of Mhp with other viruses, such as Porcine Circovirus, Porcine Reproductive and Respiratory Syndrome Virus, Swine Influenza Virus, Pseudorabies Virus, and other bacteria, such as Pasteurella multocida, Actinobacillus pleuropneumoniae have been widely studied for many years. In this review, we summarized the co-infection of Mhp with other swine pathogens based our studies made, the co-infection with other viruses and bacteria, revealed the interaction mechanism of different pathogens with Mhp in the host
\end{abstract}

\section{Co-Infection of Mycoplasma hyopneumoniae and otherswine pathogens}

Running title: Mycoplasma hyopneumoniae co-infect with pathogens

$\mathrm{Ke} \mathrm{Lu}^{1)}$, Chenyu Wang ${ }^{1)}$, Jinqi Shu ${ }^{1)}$, Enoch Obeng ${ }^{1)}$, Yuehong Wu ${ }^{1)}$, Jian Chen ${ }^{1)}$, Jianhong Shu ${ }^{1)^{*}}$, Yulong $\mathrm{He}^{1)^{*}}$

1. Department of Biopharmacy, College of Life Sciences and Medicine, Zhejiang Sci-Tech University, Hangzhou 310018, China.

*Correspondence: Yulong He: heyulong2003@163.com; Tel.: +86-571-8684-3193;

Jianhong Shu: shujh1978@163.com; Tel.: +86-571-8684-3198.

Department of Biopharmacy, College of Life Science and Medicine, Zhejiang Sci-tech University, 928 Second Avenue, Xiasha Higher Education Zone, Hangzhou, China.

\section{Summary}

Mycoplasma hyopneumoniae ( $M$. hyopneumoniae, Mhp) is an etiological agent that causes mycoplasma pneumonia of swine (MPS), this is a chronic respiratory disease present in every major swine-producing country worldwide. It is well elucidated, Mhp infections may downregulate the host immune system and enhance the infection and replication of other pathogens. However, the mechanisms of interaction between Mhp and other pathogens is still missing. Though, additional studies have reported that several cofactors 
such as bacteria, vaccination failure, stress or crowing and other swine viruses in combination with Mhp, lead to MPS. Aside these cofactors, the co-infection of Mhp with other viruses, such as Porcine Circovirus, Porcine Reproductive and Respiratory Syndrome Virus, Swine Influenza Virus, Pseudorabies Virus, and other bacteria, such as Pasteurella multocida, Actinobacillus pleuropneumoniae have been widely studied for many years. In this review, we summarized the co-infection of Mhp with other swine pathogens based our studies made, the co-infection with other viruses and bacteria, revealed the interaction mechanism of different pathogens with Mhp in the host.

\section{Keywords}

Mycoplasma hyopneumoniae (Mhp); co-infection; swine; virus; bacteria.

\section{Introduction}

Mycoplasma hyopneumoniae (M. hyopneumoniae, Mhp) forms part of the etiology of a chronic insidious lympho-histiocytic bronchopneumonia, also described as mycoplasmal pneumonia of swine (MPS) or enzootic pneumonia (EP) (DeBey, Jacobson, \& Ross, 1992), is a strong impediment to the efficiency and profitability of the global pig industry(Simionatto, Marchioro, Maes, \& Dellagostin, 2013). This disease is characterized by high morbidity but low mortality (Maes et al., 2008; Morris, Gardner, Hietala, \& Carpenter, 1995), causing cough, asthma, anorexia, and many other symptoms among off-springs, as well as showing decreased daily weight gain and significant lung lesions in the field (Tao, Shu, Chen, Wu, \& He, 2019). Mhp was first isolated from the trachea, bronchi, bronchioles and other mucosal surfaces (Blanchard et al., 1992), and it's difficult to be isolated from fields directly because of their slow growth and easy contamination. Despite the continuous improvement of mediums, in vitro culture of Mhp still remains difficult (Calus et al., 2010; Cook, Beddow, Manso-Silvan, Maglennon, \& Rycroft, 2016). This limitation, to some extent has stymied the research and the development of improved methods for disease control.

Piglets may be infected with Mhp at the early stage, with prevalence increment during the post-weaning period (Vangroenweghe, Labarque, Piepers, Strutzberg-Minder, \& Maes, 2015), the main process involved in the Mhp infection is shown in Fig. 1. Mhp infection causes immunosuppression in pigs, which provides conditions for the secondary infections. Owing to the development of modern swine production, which has intensified the production of swine on a larger-scale, mixed infections by multiple pathogens are becoming more common and serious in swine. Although the exact mechanism of Mhp infection still remains unknown, many studies have reported co-infection with other pathogens for decades, these include Porcine Circovirus (PCV) (Opriessnig \& Halbur, 2012), Porcine Reproductive and Respiratory Syndrome Virus (PRRSV), Swine Influenza Virus (SwIV), Pseudorabies Virus(PRV) and other bacterial pathogens, they also serve as possible co-factors for triggering postweaning multisystemic wasting syndrome (PMWS), which have further economic and welfare implications (Ciprian et al., 1988; Krakowka et al., 2000; Maes et al., 2008; Maes, Verdonck, Deluyker, \& de Kruif, 1996; Pogranichniy, Yoon, Harms, Sorden, \& Daniels, 2002; Wang et al., 2016; Wellenberg, Stockhofe-Zurwieden, Boersma, Jong, \& Elbers, 2004). The objective of this review was to summarize the interaction during the co-infection of Mhp with other viruses and bacteria together with other factors leading to infection in recent years, to provide the theoretical basis for studies in the future. 


\section{Co-Infection of Mycoplasma hyopneumoniae with viruses}

\subsection{Porcine Circovirus 2}

Porcine Circovirus 2 (PCV2), is a small non-enveloped DNA virus which contains a single-stranded circular genome of $1.7 \mathrm{~kb}$ belonging to the family of circoviridae (Hamel, Lin, \& Nayar, 1998; Meehan et al., 1998), this virus contributes to the considerable economic losses associated with PCV2-associated disease (PCVAD/PCVD)(Chae, 2005). The most prevalent symptoms of PCVAD/PCVD include porcine dermatitis and nephropathy syndrome (PDNS), which mainly occurs during the growing or finishing stage of pigs (Segales, 2012). According to the different of Cap gene sequence, PCV2 can be divided into several subtypes, PCV 2a-h (Bao et al., 2018; Franzo \& Segales, 2018; Yao et al., 2019), the PCV 2a and PCV 2b which are considered to be the most prevalent genotype (Patterson \& Opriessnig, 2010; Segales et al., 2008). It has been reported that, PCV2 is crucial but not a sole factor to develop this clinical disease, it must co-infect with other pathogens in order to cause this disease(Tomas, Fernandes, Valero, \& Segales, 2008).

Mhp and PCV2 are the major pathogens that cause significant financial loss (Tassis et al., 2017), coincidental infection of Mhp and PCV2 is ubiquitous in clinical conditions and contributes to a range of polymicrobial disease syndromes, such as porcine respiratory disease complex (PRDC) and PMWS (Chae, 2005; Krakowka et al., 2007; Segales, 2012). The co-infection rate of Mhp and PCV2 has been reported to be $35.5 \%(172 / 484)$ in US field cases (Pallares et al., 2002). Fablet and colleagues found that, the detection rate of Mhp DNA in a pig was $33.6 \%$ which meant that the PCV2 genome load in sera were $4.310^{4}$ copies $/ \mathrm{mL}$ (Fablet, MaroisCrehan, et al., 2012). The pigs' lymph nodes were tumefied compared to the normal size, with their lungs having some cranioventral dark purple consolidation, and accompanied by shedding of high levels of PCV2 DNA in semen in coinfection with Mhp and PCV2 cases (Opriessnig, Madson, et al., 2011). Other group also demonstrated, the severity of PCV2-associated lesions in lung and lymphoid tissues of pigs, with a number of antigens within these lesions being significantly higher compared to the control group (Opriessnig et al., 2004).

Both PCV2 and Mhp can target host immune cells and impair host defenses, resulting in a significant increase in the expression of Interferon-gamma (IFN- $\gamma$ ), Interleukin-1beta (IL-1 $\beta$ ), IL-8, Chemokine (C-C motif) ligand 5 (CCL5) and Chemokine (CXC motif) ligand 10 (CXCL10), weak stimulation of IFN- $\beta$, IL-6 and IL-10 and downregulated of IL-13 and IFN- $\alpha$ significantly (H. R. Zhang, Lunney, Baker, \& Opriessnig, 2011). Furthermore, Mhp enhanced the levels of PCV2 viraemia, whereas PCV2 did not enhance the levels of mycoplasmal nasal shedding in co-infected pigs, compared to singly Mhp or PCV2-infected pigs (Seo, Park, Park, \& Chae, 2014). PCV2 replication could be enhanced by subsequent inoculation with Mhp, however, simultaneous PCV2 and Mhp co-inoculation does not potentiate disease in conventional pigs (Sibila, Fort, Nofrarias, Perez de Rozas, et al., 2012; Wang et al., 2016). Other researchers also indicated that, concurrent infection with PCV2 and Mhp did not result in potentiation of clinical signs and lesions attributed to either infection in conventional pigs (Sibila, Fort, Nofrarias, de Rozas, et al., 2012). These results indicated that synergistic effects occur during the process of Mhp and PCV2 sequential infection, and some previous studies also demonstrated that Mhp infection in pigs normally occurs slightly before or around PCV2 infection in the field condition (Chae, 2012; Fachinger, Bischoff, Jedidia, Saalmuller, \& Elbers, 2008; Larochelle, Magar, \& D'Allaire, 2003). Therefore, the study of the interaction between Mhp and PCV2 co-infection based on sequential infection model may be closer to the field condition in pig industry.

\subsection{Porcine Reproductive and Respiratory Syndrome Virus}

Porcine Reproductive and Respiratory Syndrome Virus (PRRSV), is an enveloped, single-stranded, positive sense RNA virus in the family of Arteriviridae (Kavanova et al., 2018) and an etiologic agent that causes porcine reproductive and respiratory syndrome (PRRS), which has been estimated to be the cause of a lost $\$ 600$ million in the US swine industry at least every year (Neumann et al., 2005). The typical symptoms of 
PRRSV are characterized by blue-ear and failure in pregnant pigs (Lunney et al., 2016), also these infections can induce cell lysis, apoptosis, changes in T-cell subpopulations etc (Labarque, Van Gucht, Nauwynck, Van Reeth, \& Pensaert, 2003; Shimizu et al., 1996; Thanawongnuwech, Thacker, \& Halbur, 1997).

It has been reported that, the concurrent infection with Mhp and PRRSV is common (Chae, 2016; Fablet, Marois-Crehan, Grasland, Simon, \& Rose, 2016b; Pallares et al., 2002). Scott and colleagues have proved their hypothesis that PRRSV and Mhp can be transported via airborne route (Dee, Otake, Oliveira, \& Deen, 2009; Otake, Dee, Corzo, Oliveira, \& Deen, 2010), these characteristics of pathogens increased the difficulty to control these diseases. PRRSV replicates mainly in porcine alveolar macrophages (PAMs), dendritic cells (DC) in lungs and the upper respiratory tract (Lunney et al., 2016), resulting in viremia as early as $12 \mathrm{~h}$ post infection at the early infection stage(Wills, Doster, Galeota, Sur, \& Osorio, 2003). For the persistence period, viral replication is primarily localized in lymphoid organs, including tonsil and lymph nodes but not spleen (Allende et al., 2000; Rowland, Lawson, Rossow, \& Benfield, 2003; Wills et al., 1997) and gradual decays until the virus becomes extinct in the host (Christopher-Hennings, Nelson, Althouse, \& Lunney, 2008; Wills et al., 2003).

The PAMs from pigs infected with PRRSV have significantly downregulated the ability to kill bacteria (Solano, Bautista, Molitor, Segales, \& Pijoan, 1998). Although, some researchers have demonstrated that co-infection with Mhp and PRRSV show no potentiating effect (Van Alstine, Stevenson, \& Kanitz, 1996). Thacker and colleagues suggested that the Mhp potentiated and prolonged PRRSV-induced pneumonia clinically, macroscopically and microscopically regardless of the inoculation sequence of infection to both pathogens, whereas PRRSV did not aggravate Mhp infection in piglets when inoculated before Mhp under experimental conditions (Thacker, Halbur, Ross, Thanawongnuwech, \& Thacker, 1999; Tzika et al., 2015; Van Alstine et al., 1996). Furthermore, Fablet suggested that, the infection by Mhp was associated with PRRSV seropositive status (Fablet, Marois-Crehan, Grasland, Simon, \& Rose, 2016a). Moreover, in the concurrent infection with Mhp and PRRSV, many vital functional genes were detected as being differentially expressed (DE) in PAMs (Li et al., 2015), especially, IL-1 $\beta$ was considerably higher, which is a key component for downstream signal pathways. In addition, the co-infection of Mhp and PRRSV significantly increased the severity and duration of pneumonia in experimentally infected pigs, which was associated with induction of several proinflammatory cytokines (Thacker, Thacker, Kuhn, Hawkins, \& Waters, 2000), such as IL-1 $\alpha$, IL-1 $\beta$, IL-6, IL-8, IL-10, IL-12 and Tumor Necrosis Factor-alpha (TNF- $\alpha$ ) (Thanawongnuwech, Thacker, Halbur, \& Thacker, 2004; Thanawongnuwech \& Thacker, 2003; Thanawongnuwech, Young, Thacker, \& Thacker, 2001). Other group also found increased levels of both IL-12 and IL-10 in the respiratory tract of pigs experimentally infected with either Mhp and/or PRRSV, IFN- $\gamma$ and Insulin-like Growth Factor-I (IGF-I) production were lower and delayed in pigs co-infected with PRRSV and Mhp(Roberts \& Almond, 2003; Thanawongnuwech \& Thacker, 2003). These results suggest that the exacerbation Mhp respiratory disease may be due to viral infection which induces regulatory $\mathrm{T}$ cells (Tregs) (LeRoith et al., 2011). In contrast, Fano et al suggested that Mhp did not affect these epidemiological features of PRRSV-associated disease under the conditions of study (Fano, Pijoan, \& Dee, 2007).

Other studies also implicated that a single-dose vaccination against Mhp alone decreased the levels of PRRSV viremia and PRRSV-associated pulmonary lesions, whereas single-dose vaccination against PRRSV alone did not decrease nasal shedding of Mhp and Mhp-associated pulmonary lesions in the co-infected pigs (S. J. Park, Seo, Park, \& Chae, 2014). Combining vaccines with Mhp and PRRSV did not induce negative interaction which would reduce the efficacy of each individual vaccine (Bourry, Fablet, Simon, \& MaroisCrehan, 2015). These results indicated that, the combined vaccination is more efficient than single ones, consequently, further research should focus on the developing of combined vaccine, which can improve the convenient and efficient pig production simultaneously. 


\subsection{Swine Influenza Virus}

Swine influenza virus (SwIV), which belongs to Orthomyxoviridaefamily, causes seasonal epidemic or occasional pandemic outbreaks in pigs worldwide (Taubenberger \& Morens, 2008). SwIV can be subdivided into many subtypes, including influenza A, B, and C (Baudon, Peyre, Peiris, \& Cowling, 2017; Meiners et al., 2014).

PRDC is an economically enormous problem accompanied by slow growth performance, cough, poor food utilization etc(Baudon et al., 2017). It has been reported that SwIV and Mhp play important roles in PRDC (Deblanc et al., 2016; Deblanc et al., 2012; Fablet, Marois-Crehan, et al., 2012). SwIV can target and replicate in epithelial cells of the upper respiratory tract (Brown, Alexander, Chakraverty, Harris, \& Manvell, 1994). Coinfection with SwIV and Mhp was detected in 23 (31\%) cases in 74 lungs from 2009 to 2015 retrospective analysis (Rech et al., 2018). Although the interaction between SwIV and Mhp is minimal or even appear independent of each other (Thacker, Thacker, \& Janke, 2001), the pre-infection with Mhp was remarkably exacerbated by the clinical symptoms of pigs with $\mathrm{H} 1 \mathrm{~N} 1$ infection during the first week after virus inoculation (Deblanc et al., 2016). Furthermore, the pig lung lesion caused by inoculation with Mhp and SwIV was more severe than those inoculated with Mhp only (Yazawa et al., 2004). Deblanc and co-workers indicated that clinical signs and macroscopic lung lesions were similar in early time post-H1N1 inoculation compared to pre-Mhp infection or not pig group, and Mhp didn't affect the influenza virus replication and the IFN-induced antiviral responses in the lung, however, there is a higher inflammatory response to H1N1 infection in pre-Mhp infection group. The exact mechanism can be revealed by the massive infiltration of neutrophils and macrophages into the lungs and the increased production of pro-inflammatory cytokines (IL-6, IL-1 $\beta$ and TNF- $\alpha$ ) (Deblanc et al., 2016). Moreover, Deblanc demonstrated that Mhp and H1N1 appeared to act synergistically, as Mhp and H1N2 would compete in pigs that were previously infected with Mhp, resulting in the elimination of Mhp in the lung diaphragmatic lobes by the H1N2 (Deblanc et al., 2012). Furthermore, the miRNAs were differentially expressed (DE) and most of them were downregulated to defend the H1N1 in pulmonary alveolar macrophages during the process of H1N1 infection (Jiang et al., 2015). According to the different level of oxidative stress induced by pre-infection of Mhp, there were different outcomes from the subsequent infection with H1N1 subtype (Deblanc et al., 2013).

These results demonstrated that SwIV did not affect Mhp replication in the co-infected pig, but both Mhp and SwIV decreased or disrupt the function of the mucociliary apparatus and immunosuppression which potentially led to an increased secondary infections from opportunistic organisms under field conditions(DeBey \& Ross, 1994).

\subsection{Pseudorabies Virus}

Pseudorabies virus (Suid herpesvirus 1 or PRV) is a member of the genusVaricellovirus, and the family Herpesviridae (Peng et al., 2016). PRV is the major causative agent of Aujeszky's disease and contributes to the substantial economic losses in swine production (Freuling, Muller, \& Mettenleiter, 2017).

PRV always targets the mucosal epithelium of the pig respiratory and nervous system tissue, causing central nervous system infection and respiratory disease (Pomeranz, Reynolds, \& Hengartner, 2005). PRV infection can downregulate the function of macrophage, under conditions such as phagocytosis, killing of phagocytized bacteria, IFN- $\alpha$ production and phagosome fusion were downregulated in PRV infected pigs (Fuentes \& Pijoan, 1986; Iglesias, Pijoan, \& Molitor, 1992). Shibata and colleagues have indicated that the mean percentage of the lung lesions were $0.1 \%$ and $8.3 \%$ inoculate with Mhp alone, whereas $9.8 \%$ and $17.2 \%$ in co-infection with Mhp and PRV in post-inoculation-week (PIW) 2 and 4 respectively(Shibata et al., 1998). Consequently, PRV infection appears to have effect on the severity of experimentally induced acute Mhp in young pigs. Further studies will prove the exact mechanism involved in the interaction of PRV with Mhp, providing reference for the developing of vaccine which can combat both pathogens. 


\subsection{Co-Infection with Multiple Viruses}

Alongside single and dual infections, multiple (including triple or more viruses) infections are also prevalent among pigs(Opriessnig, Gimenez-Lirola, \& Halbur, 2011). PRDC is caused by the combination of infectious pathogens, differences in production systems and environmental factors (Hansen et al., 2010). Previous study have demonstrated that PRRSV and Mhp were well known to potentiate PCV2-associated lesions, surprisingly, PRRSV vaccine was found to enhance PCV2 replication and it can be related to the failure of PRRSV vaccine in vaccinated co-infected pigs compared to non-vaccinated co-infected pigs (C. Park, Oh, Seo, Han, \& Chae, 2013). Pallares et al have detected that the coinfection rate of PCV, PRRSV and Mhp was 16\% (77/484) in 484 cases diagnosed as PMWS (Pallares et al., 2002). A survey also demonstrated that co-infection ratios with three and four pathogens were $17.3 \%$ and $7.3 \%$ respectively in 110 pneumocystis spp. positive lung samples of Austrian pigs with pneumonia (Weissenbacher-Lang et al., 2016). Vaccination against Mhp significantly protected pigs against multiple viral infections, suggesting that vaccination against Mhp decreases the risk of PMWS and PRDC, and reduces susceptibility of pigs to the other viral pathogens (Chae, 2011). These data indicate that Mhp plays an important role in the co-infection of dual or multiple pathogens in vivo .

\section{Co-Infection of Mycoplasma hyopneumoniae with bacteria}

Pasteurella multocida (PMULT), is a capsulated, Gram-negative coccobacillus, this primary pathogen can cause debilitating and fatal porcine pneumonia, especially resulting in pleuritic (Harper, Cox, Adler, \& Boyce, 2011; Ross, 2006). Mhp and PMULT are associated with pneumonia at both the pig and herd levels, also the coincidental infections of Mhp and bacteria have also been studied for a long period (Fablet, Marois, et al., 2012). In cases with bacterial pneumonia, PMULT was the most prevalent infectious agent (Mores et al., 2015; Tocqueville, Kempf, Paboeuf, \& Marois-Crehan, 2017), while the co-infection with Mhp and PMULT in gilts and sows can render the lungs more susceptible to PMULT colonization and infection(Ciprián, Pijoan, Cruz, Camacho, \& Garza, 1988). Though pigs that have recovered from or vaccinated against Mhp infection were resistant to PMULT infection (Amass et al., 1994). In addition, Park and co-workers have elucidated the pathogenic mechanisms through which the Mhp increases the L-fucose composition to enhance adherence of PMULT type A to the bronchial and bronchiolar epithelial cells (C. Park et al., 2016). Moreover, Eileen et al reported that food which contain doxycycline was effective in fattening pigs to some extent and also controlling pneumonia which was due to PMULT and Mhp (Bousquet et al., 1998).

Actinobacillus pleuropneumoniae (APP) is a small, Gram-negative, encapsulated rod with typical coccobacillary morphology and an aetiological agent of porcine pleuropneumonia (Sassu et al., 2018). Concurrent infection with Mhp and APP is common, both of them are responsible for PRDC (Hege, Zimmermann, Scheidegger, \& Stark, 2002). Mhp and APP are considered to be the most important primary bacterial respiratory pathogens associated with lung lesions (Fablet, Marois, et al., 2012), co-inoculation with Mhp and APP can induce more severe respiratory disorders in pigs (Haimi-Hakala et al., 2017). The detection rate of $0.1 \%$ for APP and $2.6 \%$ for Mhp were discovered in 3983 farms across Switzerland (Hege et al., 2002). Marois and colleagues indicated that concurrent infection with Mhp and APP had more severe lesions compared to single does infection in experimental pigs, pigs which were infected with the APP still remained healthy and lung lesions were only observed after the co-infection with Mhp(Marois et al., 2009). Meanwhile, the phagocytic abilities of alveolar macrophage had decreased in pigs co-infected with Mhp and APP (Caruso \& Ross, 1990).

Lawsonia intracellularis(LI) are Gram-negative, obligate intracellular bacteria that cause proliferative enteropathy (PE), an economically important disease for the pig industry(Obradovic \& Wilson, 2019). Dual infections with LI and Mhp caused the epithelial thickening and post-absorptive metabolic functions altering in pigs that result in reduced nutrient absorption, reductions in growth performance and feed efficiency (Helm, Curry, Schwartz, Lonergan, \& Gabler, 2019; Helm, Outhouse, Schwartz, Lonergan, et al., 2018). 
Helm et al confirmed that, a dual enteric and respiratory pathogen challenge reduced average daily weight gain (ADG), average daily feed intake (ADFI), Gain:Feed (G:F) and tissue accretion in growing pigs(Helm, Outhouse, Schwartz, Dekkers, et al., 2018).

Moreover, studies have shown that immunosuppression caused by the predisposing of Mhp infection, can downregulate the phagocytic response, causing more serious clinical symptoms through the exposition to other bacterial pathogens, such as Bordetella bronchiseptica ,Haemophilus parasuis, Trueperella pyogenes and streptococci or staphylococci in field outbreaks of MPS(Caruso \& Ross, 1990; Maes et al., 2018). It was also, reported that concurrent infections with different Mhp strains have been detected in the same field (Vranckx et al., 2011; Vranckx, Maes, Sacristan Rdel, Pasmans, \& Haesebrouck, 2012), resulting in higher severity and prevalence of Mycoplasma-like lung lesions in slaughter pigs (Michiels, Vranckx, et al., 2017). Annelies and colleagues also demonstrated that, pigs that were co-infected with highly virulent strain F7.2C and the low virulent strain F1.12A, showed more severity lung lesions, coughed and larger log copies of Mhp in the bronchoalveolar lavag (Michiels, Arsenakis, et al., 2017). However, simultaneous infection with $M$. hyorhinis and Mhp did not aggravate the observed lung lesions (Luehrs et al., 2017), the results indicated that different virulent strain can interact with each other, but not between different species of mycoplasma. Further studies is needed to focus on the exact mechanism of how these bacterial pathogens interact with Mhp.

\section{Co-Infection of Mycoplasma hyopneumoniae with others}

Apart from co-infection of Mhp with viruses or bacteria, there are many pathogens which comes from the pig farms diet (Michiels et al., 2018). The presence of mycotoxin in foods and feeds have become a serious global challenge for animals and humans health not only in the developing as well as the developed countries(Stoev, 2013). Fumonisin mycotoxin is a metabolite produced mainly by Fusarium moniliforme Sheld, which can be subdivided into several subtypes, such as Fumonisin $\mathrm{B}_{1}\left(\mathrm{FB}_{1}\right)$, Fumonisin $\mathrm{B}_{2}\left(\mathrm{FB}_{2}\right)$ and Fumonisin $\mathrm{B}_{3}\left(\mathrm{FB}_{3}\right)$. The $\mathrm{FB}_{1}$ is considered to be the main pathogen for inducing porcine pulmonary edema(Harrison, Colvin, Greene, Newman, \& Cole, 1990) and pulmonary fibrosis that develops in cases of chronic exposure (Zomborszky-Kovács et al., 2002). Several groups have studied the interaction between Mhp-infection and $\mathrm{FB}_{1}$-fed pig, their results revealed a strong oedematous changes in the interstitium of lung in addition to deteriorated and extended bronchointerstitial pneumonic process and severe illness requiring euthanasia observed in one pig and evidence of progressive pathology in two pigs between study days 44 and 58 by using computed tomography (CT) and histopathologic review (Posa et al., 2013b; Posa et al., 2016). Therefore, $\mathrm{FB}_{1}$ aggravated the progression of infection. On the contrast, Michiels and co-workers indicated that the pigs which received feed contaminated with the mycotoxin deoxynivalenol (DON) did not show more severe disease and lesions under experimental pre-Mhp infection compared to the pigs which were fed with non-contaminated feed(Michiels et al., 2018). Furthermore, the opportunistic fungal pathogen Pneumocystis can also be co-infectied with Mhp, related interstitial pneumonia in both the Pneumocystis positive lungs and lungs with a mild Mhp infection (Kureljusic, Weissenbacher-Lang, Nedorost, Stixenberger, \& Weissenbock, 2016). Consequently, the health level of pigs to some extent can be determine by the kind of feed administered.

Parasitism can also play an important role to negatively impact the pig's ability to respond to respiratory pathogens (Tjornehoj, Eriksen, Aalbaek, \& Nansen, 1992). Some adult lungworms that are localized within the terminal bronchioles do elicit bronchitis, bronchoalveolitis, alveolar emphysema and atelectasis(Opriessnig, Gimenez-Lirola, et al., 2011). Furthermore, the pattern of gene expression in the lungs and draining lymph nodes indicated a local Th2-skewed response induced by Ascaris suum, infection with A. suum significantly compromised the effect of Mhp vaccination (Steenhard et al., 2009), which indicated that it is necessary to control parasite to provide a better environment for pig in farms. 


\section{Conclusions and Future Perspectives}

In summary, many studies have demonstrated that Mhp alone is not enough to induce PRDC or PMWS (Krakowka et al., 2000; Posa et al., 2013a; Wellenberg et al., 2004). The major route of Mhp entry is through the mucosal surfaces of respiratory tract followed by adhering to the cilium of epithelial cells(N. Zhang et al., 2019), the cilium can be gobbled up and shed due to a large number proliferation of Mhp(Tao et al., 2019) and also the duration of Mhp infection can lasts for not less than 254 days (Pieters, Pijoan, Fano, \& Dee, 2009). Mhp infection increases susceptibility of the pig to secondary infections, clinical sign of PCV2, PRRSV, SwIV, PRV and bacterial pathogens infections. Meanwhile, the secondary infection and worse habitat condition also provide a better environment for Mhp infection. The main target sites for these swine pathogens are shown in Table. 1. In addition, once infected with Mhp, pigs can excrete the pathogen lasting for 254 days postinfection (Pieters et al., 2009), this may be a high risk for off-springs infection. Moreover, farming system is a major factor influencing infection and sero-positivity for Mhp infection on pig farms, the virulence status of Mhp isolates may also affect the clinical pattern of infection (Vicca et al., 2002). Consequently, more researches are needed to improve our understanding of the interactions between different swine viruses and bacteria during co-infection with Mhp, encompassing how they interact with the host immune response and how they affect the efficacy of vaccination. At the same time, other experimental models should be developed and analyzed, and field trials can also be conducted to establish best practices for controlling this complex disease syndrome. The thrust of this review may provide point ideas in understanding of MPS and the developing of new strategies to control the disease.

\section{Acknowledgements}

We warmly thank all study participants of Department of Biopharmacy in College of Life Sciences and Medicine, Zhejiang Sci-Tech University, who helped in the realization of this study. This work was funded by Public Welfare Technology Application Research Project of Zhejiang Province [No. 2017C32049]; Key

Research and Development Program of Zhejiang Province [No. 2019C02043]; and the Science Foundation of Zhejiang Sci-Tech University [No. 16042062-Y].

\section{Conflict of interest statement}

The authors declare no conflict of interest.

\section{Data availability statement}

The datasets supporting the conclusions of this article are available in the Open Science Framework repository.

\section{References}

Allende, R., Laegreid, W. W., Kutish, G. F., Galeota, J. A., Wills, R. W., \& Osorio, F. A. (2000). Porcine reproductive and respiratory syndrome virus: description of persistence in individual pigs upon experimental infection. Journal of Virology, 74 (22), 10834-10837. doi:10.1128/jvi.74.22.10834-10837.2000

Amass, S. F., Clark, L. K., van Alstine, W. G., Bowersock, T. L., Murphy, D. A., Knox, K. E., \& Albregts, S. R. (1994). Interaction of Mycoplasma hyopneumoniae and Pasteurella multocidainfections in swine. Journal of The American Veterinary Medical Association, 204 (1), 102-107.

Bao, F., Mi, S., Luo, Q., Guo, H., Tu, C., Zhu, G., \& Gong, W. (2018). Retrospective study of porcine circovirus type 2 infection reveals a novel genotype PCV2f. Transboundary and Emerging Diseases, 65 (2), 432-440. doi:10.1111/tbed.12721

Baudon, E., Peyre, M., Peiris, M., \& Cowling, B. J. (2017). Epidemiological features of influenza circulation in swine populations: A systematic review and meta-analysis. Public Library of Science, 12 (6), e0179044. doi:10.1371/journal.pone.0179044 
Blanchard, B., Vena, M. M., Cavalier, A., Le Lannic, J., Gouranton, J., \& Kobisch, M. (1992). Electron microscopic observation of the respiratory tract of SPF piglets inoculated with Mycoplasma hyopneumoniae . Veterinary Microbiology, 30 (4), 329-341. doi:10.1016/0378-1135(92)90020-t

Bourry, O., Fablet, C., Simon, G., \& Marois-Crehan, C. (2015). Efficacy of combined vaccination against Mycoplasma hyopneumoniae and porcine reproductive and respiratory syndrome virus in dually infected pigs. Veterinary Microbiology, 180 (3-4), 230-236. doi:10.1016/j.vetmic.2015.09.015

Bousquet, E., Pommier, P., Wessel-Robert, S., Morvan, H., Benoit-Valiergue, H., \& Laval, A. (1998). Efficacy of doxycycline in feed for the control of pneumonia caused by Pasteurella multocidaand Mycoplasma hyopneumoniae in fattening pigs. Veterinary Record, 143 (10), 269-272. doi:10.1136/vr.143.10.269

Brown, I. H., Alexander, D. J., Chakraverty, P., Harris, P. A., \& Manvell, R. J. (1994). Isolation of an influenza A virus of unusual subtype (H1N7) from pigs in England, and the subsequent experimental transmission from pig to pig. Veterinary Microbiology, 39 (1-2), 125-134. doi:10.1016/0378-1135(94)90093-0

Calus, D., Maes, D., Vranckx, K., Villareal, I., Pasmans, F., \& Haesebrouck, F. (2010). Validation of ATP luminometry for rapid and accurate titration of Mycoplasma hyopneumoniae in Friis medium and a comparison with the color changing units assay. Journal of The American Veterinary Medical Association, 83 (3), 335-340. doi:10.1016/j.mimet.2010.09.001

Caruso, J. P., \& Ross, R. F. (1990). Effects of Mycoplasma hyopneumoniae and Actinobacillus (Haemophilus) pleuropneumoniae infections on alveolar macrophage functions in swine. American Journal of Veterinary Research, 51 (2), 227-231.

Chae, C. (2005). A review of porcine circovirus 2-associated syndromes and diseases. Veterinary Journal, 169 (3), 326-336. doi:10.1016/j.tvjl.2004.01.012

Chae, C. (2011). Vaccinating pigs against Mycoplasma hyopneumoniae infection: failure to prevent transmission. Veterinary Journal, 188 (1), 7-8. doi:10.1016/j.tvjl.2010.05.032

Chae, C. (2012). Porcine circovirus type 2 and its associated diseases in Korea. Virus Research, 164 (1-2), 107-113. doi:10.1016/j.virusres.2011.10.013

Chae, C. (2016). Porcine respiratory disease complex: Interaction of vaccination and porcine circovirus type 2, porcine reproductive and respiratory syndrome virus, and Mycoplasma hyopneumoniae .Veterinary Journal, 212 , 1-6. doi:10.1016/j.tvj1.2015.10.030

Christopher-Hennings, J., Nelson, E. A., Althouse, G. C., \& Lunney, J. (2008). Comparative antiviral and proviral factors in semen and vaccines for preventing viral dissemination from the male reproductive tract and semen. Animal Health Research Reviews, 9 (1), 59-69. doi:10.1017/s1466252307001387

Ciprián, A., Pijoan, C., Cruz, T., Camacho, J., \& Garza, M. D. L. (1988). Mycoplasma hyopneumoniae increases the susceptibility of pigs to experimental Pasteurella multocda pneumonia. Canadian Journal of Veterinary Research, 52 (4), 434-438.

Ciprian, A., Pijoan, C., Cruz, T., Camacho, J., Tortora, J., Colmenares, G., de la Garza, M. (1988). Mycoplasma hyopneumoniae increases the susceptibility of pigs to experimental Pasteurella multocidapneumonia. Canadian Journal of Veterinary Research, 52 (4), 434-438.

Cook, B. S., Beddow, J. G., Manso-Silvan, L., Maglennon, G. A., \& Rycroft, A. N. (2016). Selective medium for culture of Mycoplasma hyopneumoniae. Veterinary Microbiology, 195 , 158-164. doi:10.1016/j.vetmic.2016.09.022

DeBey, M. C., Jacobson, C. D., \& Ross, R. F. (1992). Histochemical and morphologic changes of porcine airway epithelial cells in response to infection with Mycoplasma hyopneumoniae. American Journal of Veterinary Research, 53 (9), 1705-1710. 
DeBey, M. C., \& Ross, R. F. (1994). Ciliostasis and loss of cilia induced by Mycoplasma hyopneumoniae in porcine tracheal organ cultures. Infection and Immunity, 62 (12), 5312-5318.

Deblanc, C., Delgado-Ortega, M., Gorin, S., Berri, M., Paboeuf, F., Berthon, P., Simon, G. (2016). Mycoplasma hyopneumoniae does not affect the interferon-related anti-viral response but predisposes the pig to a higher level of inflammation following swine influenza virus infection. Journal of General Virology, 97 (10), 2501-2515. doi:10.1099/jgv.0.000573

Deblanc, C., Gorin, S., Queguiner, S., Gautier-Bouchardon, A. V., Ferre, S., Amenna, N., Simon, G. (2012). Pre-infection of pigs with Mycoplasma hyopneumoniae modifies outcomes of infection with European swine influenza virus of H1N1, but not H1N2, subtype. Veterinary Microbiology, 157 (1-2), 96-105. doi:10.1016/j.vetmic.2011.12.027

Deblanc, C., Robert, F., Pinard, T., Gorin, S., Queguiner, S., Gautier-Bouchardon, A. V., Simon, G. (2013). Pre-infection of pigs withMycoplasma hyopneumoniae induces oxidative stress that influences outcomes of a subsequent infection with a swine influenza virus of H1N1 subtype. Veterinary Microbiology, 162 (2-4), 643-651. doi:10.1016/j.vetmic.2012.11.028

Dee, S., Otake, S., Oliveira, S., \& Deen, J. (2009). Evidence of long distance airborne transport of porcine reproductive and respiratory syndrome virus and Mycoplasma hyopneumoniae. Veterinary Research, 40 (4). doi:ARTN 3910.1051/vetres/2009022

Fablet, C., Marois-Crehan, C., Grasland, B., Simon, G., \& Rose, N. (2016a). Factors associated with herdlevel PRRSV infection and age-time to seroconversion in farrow-to-finish herds. Veterinary Microbiology, 192 , 10-20. doi:10.1016/j.vetmic.2016.06.006

Fablet, C., Marois-Crehan, C., Grasland, B., Simon, G., \& Rose, N. (2016b). Factors associated with herdlevel PRRSV infection and age-time to seroconversion in farrow-to-finish herds. Veterinary Microbiology, 192 , 10-20. doi:10.1016/j.vetmic.2016.06.006

Fablet, C., Marois-Crehan, C., Simon, G., Grasland, B., Jestin, A., Kobisch, M., Rose, N. (2012). Infectious agents associated with respiratory diseases in 125 farrow-to-finish pig herds: a cross-sectional study. Veterinary Microbiology, 157 (1-2), 152-163. doi:10.1016/j.vetmic.2011.12.015

Fablet, C., Marois, C., Dorenlor, V., Eono, F., Eveno, E., Jolly, J. P., Rose, N. (2012). Bacterial pathogens associated with lung lesions in slaughter pigs from 125 herds. Research in Veterinary Science, 93 (2), 627-630. doi:10.1016/j.rvsc.2011.11.002

Fachinger, V., Bischoff, R., Jedidia, S. B., Saalmuller, A., \& Elbers, K. (2008). The effect of vaccination against porcine circovirus type 2 in pigs suffering from porcine respiratory disease complex. Vaccine, 26 (11), 1488-1499. doi:10.1016/j.vaccine.2007.11.053

Fano, E., Pijoan, C., \& Dee, S. (2007). Infection dynamics of porcine reproductive and respiratory syndrome virus in a continuous-flow population of pigs also infected with Mycoplasma hyopneumoniae .Veterinary Record, 161 (15), 515-520. doi:10.1136/vr.161.15.515

Franzo, G., \& Segales, J. (2018). Porcine circovirus 2 (PCV-2) genotype update and proposal of a new genotyping methodology. Public Library of Science, 13 (12), e0208585. doi:10.1371/journal.pone.0208585

Freuling, C. M., Muller, T. F., \& Mettenleiter, T. C. (2017). Vaccines against pseudorabies virus (PrV). Veterinary Microbiology, 206 , 3-9. doi:10.1016/j.vetmic.2016.11.019

Fuentes, M., \& Pijoan, C. (1986). Phagocytosis and intracellular killing of Pasteurella multocida by porcine alveolar macrophages after infection with pseudorabies virus. Veterinary immunology and immunopathology, 13 (1-2), 165-172. doi:10.1016/0165-2427(86)90057-7

Haimi-Hakala, M., Halli, O., Laurila, T., Raunio-Saarnisto, M., Nokireki, T., Laine, T., Heinonen, M. (2017). Etiology of acute respiratory disease in fattening pigs in Finland. Porcine Health Management, 3 , 19. 


\section{doi:10.1186/s40813-017-0065-2}

Hamel, A. L., Lin, L. L., \& Nayar, G. P. (1998). Nucleotide sequence of porcine circovirus associated with postweaning multisystemic wasting syndrome in pigs. Journal of Virology, 72 (6), 5262-5267.

Hansen, M. S., Pors, S. E., Jensen, H. E., Bille-Hansen, V., Bisgaard, M., Flachs, E. M., \& Nielsen, O. L. (2010). An investigation of the pathology and pathogens associated with porcine respiratory disease complex in Denmark. Journal of Comparative Pathology, 143 (2-3), 120-131. doi:10.1016/j.jcpa.2010.01.012

Harper, M., Cox, A. D., Adler, B., \& Boyce, J. D. (2011).Pasteurella multocida lipopolysaccharide: the long and the short of it. Veterinary Microbiology, 153 (1-2), 109-115. doi:10.1016/j.vetmic.2011.05.022

Harrison, L. R., Colvin, B. M., Greene, J. T., Newman, L. E., \& Cole, J. R., Jr. (1990). Pulmonary edema and hydrothorax in swine produced by fumonisin B1, a toxic metabolite of Fusarium moniliforme. Journal of Veterinary Diagnostic Investigation, 2 (3), 217-221. doi:10.1177/104063879000200312

Hege, R., Zimmermann, W., Scheidegger, R., \& Stark, K. D. (2002). Incidence of reinfections with Mycoplasma hyopneumoniae andActinobacillus pleuropneumoniae in pig farms located in respiratory-disease-free regions of Switzerland-identification and quantification of risk factors. Acta Veterinaria Scandinavica, 43 (3), 145-156.

Helm, E. T., Curry, S. M., Schwartz, K. J., Lonergan, S. M., \& Gabler, N. K. (2019). Mycoplasma hyopneumoniae -Lawsonia intracellularis dual challenge modulates intestinal integrity and function1. Journal of Animal Science, 97 (6), 2376-2384. doi:10.1093/jas/skz112

Helm, E. T., Outhouse, A. C., Schwartz, K. J., Dekkers, J. C. M., Lonergan, S. M., Rauw, W. M., \& Gabler, N. K. (2018). Impact of Mycoplasma hyopneumoniae and Lawsonia intracellularis on the performance of pigs divergently selected for feed efficiency.Journal of Animal Science, 96 (2), 462-472. doi:10.1093/jas/skx074

Helm, E. T., Outhouse, A. C., Schwartz, K. J., Lonergan, S. M., Curry, S. M., Dekkers, J. C. M., \& Gabler, N. K. (2018). Metabolic adaptation of pigs to a Mycoplasma hyopneumoniae and Lawsonia intracellularis dual challenge. Journal of Animal Science, 96 (8), 3196-3207. doi:10.1093/jas/sky220

Iglesias, G., Pijoan, C., \& Molitor, T. (1992). Effects of pseudorabies virus infection upon cytotoxicity and antiviral activities of porcine alveolar macrophages. Comparative Immunology, Microbiology and Infectious Diseases, 15 (4), 249-259. doi:10.1016/0147-9571(92)90004-b

Jiang, P., Zhou, N., Chen, X., Zhao, X., Li, D., Wang, F., Zhang, D. (2015). Integrative analysis of differentially expressed microRNAs of pulmonary alveolar macrophages from piglets during H1N1 swine influenza A virus infection. Scientific Reports, 5 , 8167. doi:10.1038/srep08167

Kavanova, L., Matiaskova, K., Leva, L., Nedbalcova, K., Matiasovic, J., Faldyna, M., \& Salat, J. (2018). Concurrent infection of monocyte-derived macrophages with porcine reproductive and respiratory syndrome virus and Haemophilus parasuis : A role of IFN alpha in pathogenesis of co-infections. Veterinary Microbiology, 225 , 64-71. doi:10.1016/j.vetmic.2018.09.016

Krakowka, S., Ellis, J., McNeilly, F., Waldner, C., Rings, D. M., \& Allan, G. (2007). Mycoplasma hyopneumoniae bacterins and porcine circovirus type 2 (PCV2) infection: induction of postweaning multisystemic wasting syndrome (PMWS) in the gnotobiotic swine model of PCV2-associated disease. Canadian Veterinary Journal-Revue Veterinaire Canadienne, 48 (7), 716-724.

Krakowka, S., Ellis, J. A., Meehan, B., Kennedy, S., McNeilly, F., \& Allan, G. (2000). Viral wasting syndrome of swine: experimental reproduction of postweaning multisystemic wasting syndrome in gnotobiotic swine by coinfection with porcine circovirus 2 and porcine parvovirus. Veterinary Pathology, 37 (3), 254-263. doi:10.1354/vp.37-3-254

Kureljusic, B., Weissenbacher-Lang, C., Nedorost, N., Stixenberger, D., \& Weissenbock, H. (2016). Association between Pneumocystis spp . and co-infections with Bordetella bronchiseptica, Mycoplasma hyopneu- 
moniae and Pasteurella multocida in Austrian pigs with pneumonia. Veterinary Journal, 207, 177-179. doi:10.1016/j.tvjl.2015.11.003

Labarque, G., Van Gucht, S., Nauwynck, H., Van Reeth, K., \& Pensaert, M. (2003). Apoptosis in the lungs of pigs infected with porcine reproductive and respiratory syndrome virus and associations with the production of apoptogenic cytokines. Veterinary Research, 34 (3), 249-260. doi:10.1051/vetres:2003001

Larochelle, R., Magar, R., \& D'Allaire, S. (2003). Comparative serologic and virologic study of commercial swine herds with and without postweaning multisystemic wasting syndrome. Canadian Journal of Veterinary Research, 67 (2), 114-120.

LeRoith, T., Hammond, S., Todd, S. M., Ni, Y., Cecere, T., \& Pelzer, K. D. (2011). A modified live PRRSV vaccine and the pathogenic parent strain induce regulatory $\mathrm{T}$ cells in pigs naturally infected withMycoplasma hyopneumoniae. Veterinary Immunology and Immunopathology, 140 (3-4), 312-316. doi:10.1016/j.vetimm.2010.12.011

Li, B., Du, L., Xu, X., Sun, B., Yu, Z., Feng, Z., He, K. (2015). Transcription analysis on response of porcine alveolar macrophages to co-infection of the highly pathogenic porcine reproductive and respiratory syndrome virus and Mycoplasma hyopneumoniae.Virus Research, 196 , 60-69. doi:10.1016/j.virusres.2014.11.006

Luehrs, A., Siegenthaler, S., Grutzner, N., Grosse Beilage, E., Kuhnert, P., \& Nathues, H. (2017). Occurrence of Mycoplasma hyorhinisinfections in fattening pigs and association with clinical signs and pathological lesions of Enzootic Pneumonia. Veterinary Microbiology, 203 , 1-5. doi:10.1016/j.vetmic.2017.02.001

Lunney, J. K., Fang, Y., Ladinig, A., Chen, N., Li, Y., Rowland, B., \& Renukaradhya, G. J. (2016). Porcine Reproductive and Respiratory Syndrome Virus (PRRSV): Pathogenesis and Interaction with the Immune System. Annual Review of Animal Biosciences, 4 , 129-154. doi:10.1146/annurev-animal-022114-111025

Maes, D., Segales, J., Meyns, T., Sibila, M., Pieters, M., \& Haesebrouck, F. (2008). Control of Mycoplasma hyopneumoniaeinfections in pigs. Veterinary Microbiology, 126 (4), 297-309. doi:10.1016/j.vetmic.2007.09.008

Maes, D., Sibila, M., Kuhnert, P., Segales, J., Haesebrouck, F., \& Pieters, M. (2018). Update on Mycoplasma hyopneumoniae infections in pigs: Knowledge gaps for improved disease control. Transboundary and Emerging Diseases, 65 Suppl 1 , 110-124. doi:10.1111/tbed.12677

Maes, D., Verdonck, M., Deluyker, H., \& de Kruif, A. (1996). Enzootic pneumonia in pigs. Veterinary Quarterly, 18 (3), 104-109. doi:10.1080/01652176.1996.9694628

Marois, C., Gottschalk, M., Morvan, H., Fablet, C., Madec, F., \& Kobisch, M. (2009). Experimental infection of SPF pigs withActinobacillus pleuropneumoniae serotype 9 alone or in association with Mycoplasma hyopneumoniae . Veterinary Microbiology, 135 (3-4), 283-291. doi:10.1016/j.vetmic.2008.09.061

Meehan, B. M., McNeilly, F., Todd, D., Kennedy, S., Jewhurst, V. A., Ellis, J. A., Allan, G. M. (1998). Characterization of novel circovirus DNAs associated with wasting syndromes in pigs. Journal of General Virology, 79 ( Pt 9) , 2171-2179. doi:10.1099/0022-1317-79-9-2171

Meiners, C., Loesken, S., Doehring, S., Starick, E., Pesch, S., Maas, A., Grosse Beilage, E. (2014). Field study on swine influenza virus (SIV) infection in weaner pigs and sows. Tierarztl Prax Ausg G Grosstiere Nutztiere, 42 (6), 351-359. doi:10.15653/tpg-131130

Michiels, A., Arsenakis, I., Boyen, F., Krejci, R., Haesebrouck, F., \& Maes, D. (2017). Efficacy of one dose vaccination against experimental infection with two Mycoplasma hyopneumoniae strains. Bmc Veterinary Research, 13 (1), 274. doi:10.1186/s12917-017-1195-0

Michiels, A., Arsenakis, I., Matthijs, A., Boyen, F., Haesaert, G., Audenaert, K., Maes, D. (2018). Clinical impact of deoxynivalenol, 3-acetyl-deoxynivalenol and 15-acetyl-deoxynivalenol on the severity of an experimental Mycoplasma hyopneumoniae infection in pigs.Bmc Veterinary Research, 14 (1), 190. doi:10.1186/s12917018-1502-4 
Michiels, A., Vranckx, K., Piepers, S., Del Pozo Sacristan, R., Arsenakis, I., Boyen, F., Maes, D. (2017). Impact of diversity of Mycoplasma hyopneumoniae strains on lung lesions in slaughter pigs. Veterinary Research, 48 (1), 2. doi:10.1186/s13567-016-0408-z

Mores, M. A. Z., Oliveira Filho, J. X., Rebelatto, R., Klein, C. S., Barcellos, D. E. N., \& Coldebella, A., \& Morés, N. (2015). Aspectos patológicos e microbiológicos das doenças respiratórias em suínos de terminação no Brasil. Pesquisa Veterinaria Brasileira (35), 725-733. doi:10.1590/S0100-736X2015000800004

Morris, C. R., Gardner, I. A., Hietala, S. K., \& Carpenter, T. E. (1995). Enzootic pneumonia: comparison of cough and lung lesions as predictors of weight gain in swine. Canadian Journal of Veterinary Research, 59 (3), 197-204.

Neumann, E. J., Kliebenstein, J. B., Johnson, C. D., Mabry, J. W., Bush, E. J., Seitzinger, A. H., Zimmerman, J. J. (2005). Assessment of the economic impact of porcine reproductive and respiratory syndrome on swine production in the United States. Journal of The American Veterinary Medical Association, 227 (3), 385-392. doi:10.2460/javma.2005.227.385

Obradovic, M. R., \& Wilson, H. L. (2019). Immune response and protection against Lawsonia intracellularis infections in pigs.Veterinary Immunology and Immunopathology, 219 , 109959. doi:10.1016/j.vetimm.2019.109959

Opriessnig, T., Gimenez-Lirola, L. G., \& Halbur, P. G. (2011). Polymicrobial respiratory disease in pigs. Animal Health Research Reviews, 12 (2), 133-148. doi:10.1017/s1466252311000120

Opriessnig, T., \& Halbur, P. G. (2012). Concurrent infections are important for expression of porcine circovirus associated disease. Virus Research, 164 (1-2), 20-32. doi:10.1016/j.virusres.2011.09.014

Opriessnig, T., Madson, D. M., Schalk, S., Brockmeier, S., Shen, H. G., Beach, N. M., Halbur, P. G. (2011). Porcine circovirus type 2 (PCV2) vaccination is effective in reducing disease and PCV2 shedding in semen of boars concurrently infected with PCV2 and Mycoplasma hyopneumoniae. Theriogenology, 76 (2), 351-360. doi:10.1016/j.theriogenology.2011.02.014

Opriessnig, T., Thacker, E. L., Yu, S., Fenaux, M., Meng, X. J., \& Halbur, P. G. (2004). Experimental reproduction of postweaning multisystemic wasting syndrome in pigs by dual infection withMycoplasma hyopneumoniae and porcine circovirus type 2. Veterinary Pathology, 41 (6), 624-640. doi:10.1354/vp.41-6624

Otake, S., Dee, S., Corzo, C., Oliveira, S., \& Deen, J. (2010). Long-distance airborne transport of infectious PRRSV and Mycoplasma hyopneumoniae from a swine population infected with multiple viral variants. Veterinary Microbiology, 145 (3-4), 198-208. doi:10.1016/j.vetmic.2010.03.028

Pallares, F. J., Halbur, P. G., Opriessnig, T., Sorden, S. D., Villar, D., Janke, B. H., Hoffman, L. J. (2002). Porcine circovirus type 2 (PCV-2) coinfections in US field cases of postweaning multisystemic wasting syndrome (PMWS). Journal of Veterinary Diagnostic Investigation, 14 (6), 515-519. doi:10.1177/104063870201400614

Park, C., Jeong, J., Kang, I., Choi, K., Park, S. J., \& Chae, C. (2016). Increased fucosyl glycoconjugate by Mycoplasma hyopneumoniae enhances adherences of Pasteurella multocida type A in the ciliated epithelial cells of the respiratory tract. Bmc Veterinary Research, 12 , 25. doi:10.1186/s12917-016-0650-7

Park, C., Oh, Y., Seo, H. W., Han, K., \& Chae, C. (2013). Comparative effects of vaccination against porcine circovirus type 2 (PCV2) and porcine reproductive and respiratory syndrome virus (PRRSV) in a PCV2-PRRSV challenge model. Clinical and Vaccine Immunology, 20 (3), 369-376. doi:10.1128/cvi.00497-12

Park, S. J., Seo, H. W., Park, C., \& Chae, C. (2014). Interaction between single-dose Mycoplasma hyopneumoniae and porcine reproductive and respiratory syndrome virus vaccines on dually infected pigs. Research in Veterinary Science, 96 (3), 516-522. doi:10.1016/j.rvsc.2014.03.009 
Patterson, A. R., \& Opriessnig, T. (2010). Epidemiology and horizontal transmission of porcine circovirus type 2 (PCV2). Animal Health Research Reviews, 11 (2), 217-234. doi:10.1017/s1466252310000162

Peng, Z., Ouyang, T., Pang, D., Ma, T., Chen, X., Guo, N., Ren, L. (2016). Pseudorabies virus can escape from CRISPR-Cas9-mediated inhibition. Virus Research, 223 , 197-205. doi:10.1016/j.virusres.2016.08.001

Pieters, M., Pijoan, C., Fano, E., \& Dee, S. (2009). An assessment of the duration of Mycoplasma hyopneumoniae infection in an experimentally infected population of pigs. Veterinary Microbiology, 134 (3-4), 261-266. doi:10.1016/j.vetmic.2008.08.016

Pogranichniy, R. M., Yoon, K. J., Harms, P. A., Sorden, S. D., \& Daniels, M. (2002). Case-control study on the association of porcine circovirus type 2 and other swine viral pathogens with postweaning multisystemic wasting syndrome. Journal of Veterinary Diagnostic Investigation Official Publication of the American Association of Veterinary Laboratory Diagnosticians Inc, 14 (6), 449.

Pomeranz, L. E., Reynolds, A. E., \& Hengartner, C. J. (2005). Molecular biology of pseudorabies virus: impact on neurovirology and veterinary medicine. Microbiology and Molecular Biology Reviews, 69 (3), 462-500. doi:10.1128/mmbr.69.3.462-500.2005

Posa, R., Magyar, T., Stoev, S. D., Glavits, R., Donko, T., Repa, I., \& Kovacs, M. (2013a). Use of computed tomography and histopathologic review for lung lesions produced by the interaction between Mycoplasma hyopneumoniae and fumonisin mycotoxins in pigs. Veterinary Pathology, 50 (6), 971-979. doi:10.1177/0300985813480510

Posa, R., Magyar, T., Stoev, S. D., Glavits, R., Donko, T., Repa, I., \& Kovacs, M. (2013b). Use of Computed Tomography and Histopathologic Review for Lung Lesions Produced by the Interaction Between Mycoplasma hyopneumoniae and Fumonisin Mycotoxins in Pigs. Veterinary Pathology, 50 (6), 971-979. doi:10.1177/0300985813480510

Posa, R., Stoev, S., Kovacs, M., Donko, T., Repa, I., \& Magyar, T. (2016). A comparative pathological finding in pigs exposed to fumonisin B1 and/or Mycoplasma hyopneumoniae. Toxicology and Industrial Health, 32 (6), 998-1012. doi:10.1177/0748233714543735

Rech, R. R., Gava, D., Silva, M. C., Fernandes, L. T., Haach, V., Ciacci-Zanella, J. R., \& Schaefer, R. (2018). Porcine respiratory disease complex after the introduction of H1N1/2009 influenza virus in Brazil. Zoonoses Public Health, 65 (1), e155-e161. doi:10.1111/zph.12424

Roberts, N. E., \& Almond, G. W. (2003). Infection of growing swine with porcine reproductive and respiratory syndrome virus and Mycoplasma hyopneumoniae -effects on growth, serum metabolites, and insulin-like growth factor-I. Canadian Veterinary Journal-Revue Veterinaire Canadienne, 44 (1), 31-37.

Ross, R. F. (2006). Pasteurella multocida and its role in porcine pneumonia. Animal Health Research Reviews, 7 (1-2), 13-29. doi:10.1017/s1466252307001211

Rowland, R. R., Lawson, S., Rossow, K., \& Benfield, D. A. (2003). Lymphoid tissue tropism of porcine reproductive and respiratory syndrome virus replication during persistent infection of pigs originally exposed to virus in utero. Veterinary Microbiology, 96 (3), 219-235. doi:10.1016/j.vetmic.2003.07.006

Sassu, E. L., Bosse, J. T., Tobias, T. J., Gottschalk, M., Langford, P. R., \& Hennig-Pauka, I. (2018). Update on Actinobacillus pleuropneumoniae -knowledge, gaps and challenges. Transboundary and Emerging Diseases, 65 Suppl 1, 72-90. doi:10.1111/tbed.12739

Segales, J. (2012). Porcine circovirus type 2 (PCV2) infections: clinical signs, pathology and laboratory diagnosis. Virus Research, 164 (1-2), 10-19. doi:10.1016/j.virusres.2011.10.007

Segales, J., Olvera, A., Grau-Roma, L., Charreyre, C., Nauwynck, H., Larsen, L., Allan, G. (2008). PCV-2 genotype definition and nomenclature. Veterinary Record, 162 (26), 867-868. doi:10.1136/vr.162.26.867 
Seo, H. W., Park, S. J., Park, C., \& Chae, C. (2014). Interaction of porcine circovirus type 2 and Mycoplasma hyopneumoniae vaccines on dually infected pigs. Vaccine, 32 (21), 2480-2486. doi:10.1016/j.vaccine.2014.02.088

Shibata, I., Okada, M., Urono, K., Samegai, Y., Ono, M., Sakano, T., \& Sato, S. (1998). Experimental dual infection of cesarean-derived, colostrum-deprived pigs with Mycoplasma hyopneumoniae and Pseudorabies virus. Journal of Veterinary Science, 60 (3), 295-300. doi:10.1292/jvms.60.295

Shimizu, M., Yamada, S., Kawashima, K., Ohashi, S., Shimizu, S., \& Ogawa, T. (1996). Changes of lymphocyte subpopulations in pigs infected with porcine reproductive and respiratory syndrome (PRRS) virus. Veterinary immunology and immunopathology, 50 (1-2), 19-27. doi:10.1016/0165-2427(95)05494-4

Sibila, M., Fort, M., Nofrarias, M., de Rozas, A. P., Galindo-Cardiel, I., Mateu, E., \& Segales, J. (2012). Simultaneous Porcine Circovirus Type 2 and Mycoplasma hyopneumoniae Co-inoculation does not Potentiate Disease in Conventional Pigs. Journal of Comparative Pathology, 147 (2-3), 285-295. doi:10.1016/j.jcpa.2012.01.003

Sibila, M., Fort, M., Nofrarias, M., Perez de Rozas, A., Galindo-Cardiel, I., Mateu, E., \& Segales, J. (2012). Simultaneous porcine circovirus type 2 and Mycoplasma hyopneumoniaeco-inoculation does not potentiate disease in conventional pigs.Journal of Comparative Pathology, 147 (2-3), 285-295. doi:10.1016/j.jcpa.2012.01.003

Simionatto, S., Marchioro, S. B., Maes, D., \& Dellagostin, O. A. (2013). Mycoplasma hyopneumoniae : from disease to vaccine development. Veterinary Microbiology, 165 (3-4), 234-242. doi:10.1016/j.vetmic.2013.04.019

Solano, G. I., Bautista, E., Molitor, T. W., Segales, J., \& Pijoan, C. (1998). Effect of porcine reproductive and respiratory syndrome virus infection on the clearance of Haemophilus parasuis by porcine alveolar macrophages. Canadian Journal of Veterinary Research, 62 (4), 251-256.

Steenhard, N. R., Jungersen, G., Kokotovic, B., Beshah, E., Dawson, H. D., Urban, J. F., Jr., Thamsborg, S. M. (2009). Ascaris suum infection negatively affects the response to a Mycoplasma hyopneumoniaevaccination and subsequent challenge infection in pigs. Vaccine, 27 (37), 5161-5169. doi:10.1016/j.vaccine.2009.05.075

Stoev, S. D. (2013). Food safety and increasing hazard of mycotoxin occurrence in foods and feeds. Critical Reviews in Food Science and Nutrition, 53 (9), 887-901. doi:10.1080/10408398.2011.571800

Tao, Y., Shu, J., Chen, J., Wu, Y., \& He, Y. (2019). A concise review of vaccines against Mycoplasma hyopneumoniae . Research in Veterinary Science, 123 , 144-152. doi:10.1016/j.rvsc.2019.01.007

Tassis, P. D., Tsakmakidis, I., Papatsiros, V. G., Koulialis, D., Nell, T., Brellou, G., \& Tzika, E. D. (2017). A randomized controlled study on the efficacy of a novel combination vaccine against enzootic pneumonia (Mycoplasma hyopneumoniae) and porcine Circovirus type 2 (PCV2) in the presence of strong maternally derived PCV2 immunity in pigs. Bmc Veterinary Research, 13 (1), 91. doi:10.1186/s12917-017-1014-7

Taubenberger, J. K., \& Morens, D. M. (2008). The pathology of influenza virus infections. Annual Review of Pathology, 3 , 499-522. doi:10.1146/annurev.pathmechdis.3.121806.154316

Thacker, E. L., Halbur, P. G., Ross, R. F., Thanawongnuwech, R., \& Thacker, B. J. (1999). Mycoplasma hyopneumoniae potentiation of porcine reproductive and respiratory syndrome virus-induced pneumonia. Journal of Clinical Microbiology, 37 (3), 620-627.

Thacker, E. L., Thacker, B. J., \& Janke, B. H. (2001). Interaction between Mycoplasma hyopneumoniae and swine influenza virus. Journal of Clinical Microbiology, 39 (7), 2525-2530. doi:10.1128/jcm.39.7.25252530.2001

Thacker, E. L., Thacker, B. J., Kuhn, M., Hawkins, P. A., \& Waters, W. R. (2000). Evaluation of local and systemic immune responses induced by intramuscular injection of a Mycoplasma hyopneumoniae bacterin to 
pigs. American Journal of Veterinary Research, 61 (11), 1384-1389. doi:10.2460/ajvr.2000.61.1384

Thanawongnuwech, R., Thacker, B., Halbur, P., \& Thacker, E. L. (2004). Increased production of proinflammatory cytokines following infection with porcine reproductive and respiratory syndrome virus and Mycoplasma hyopneumoniae. Clinical and Diagnostic Laboratory Immunology, 11 (5), 901-908. doi:10.1128/cdli.11.5.901-908.2004

Thanawongnuwech, R., \& Thacker, E. L. (2003). Interleukin-10, interleukin-12, and interferon-gamma levels in the respiratory tract following Mycoplasma hyopneumoniae and PRRSV infection in pigs. Viral Immunology, 16 (3), 357-367. doi:10.1089/088282403322396154

Thanawongnuwech, R., Thacker, E. L., \& Halbur, P. G. (1997). Effect of porcine reproductive and respiratory syndrome virus (PRRSV) (isolate ATCC VR-2385) infection on bactericidal activity of porcine pulmonary intravascular macrophages (PIMs): in vitro comparisons with pulmonary alveolar macrophages (PAMs). Veterinary immunology and immunopathology, 59 (3-4), 323-335. doi:10.1016/s0165-2427(97)00078-0

Thanawongnuwech, R., Young, T. F., Thacker, B. J., \& Thacker, E. L. (2001). Differential production of proinflammatory cytokines: in vitro PRRSV and Mycoplasma hyopneumoniae co-infection model. Veterinary immunology and immunopathology, 79 (1-2), 115-127. doi:10.1016/s0165-2427(01)00243-4

Tjornehoj, K., Eriksen, L., Aalbaek, B., \& Nansen, P. (1992). Interaction between Ascaris suum and Pasteurella multocida in the lungs of mice. Parasitology Research, 78 (6), 525-528. doi:10.1007/bf00931575

Tocqueville, V., Kempf, I., Paboeuf, F., \& Marois-Crehan, C. (2017). Quantification of Pasteurella multocida in experimentally infected pigs using a real-time PCR assay. Research in Veterinary Science, 112, 177-184. doi:10.1016/j.rvsc.2017.04.016

Tomas, A., Fernandes, L. T., Valero, O., \& Segales, J. (2008). A meta-analysis on experimental infections with porcine circovirus type 2 (PCV2). Veterinary Microbiology, 132 (3-4), 260-273. doi:10.1016/j.vetmic.2008.05.023

Tzika, E. D., Tassis, P. D., Koulialis, D., Papatsiros, V. G., Nell, T., Brellou, G., \& Tsakmakidis, I. (2015). Field efficacy study of a novel ready-to-use vaccine against Mycoplasma hyopneumoniae and porcine circovirus type 2 in a Greek farm. Porcine Health Management, 1 . doi:UNSP 1510.1186/s40813-015-0006-x

Van Alstine, W. G., Stevenson, G. W., \& Kanitz, C. L. (1996). Porcine reproductive and respiratory syndrome virus does not exacerbateMycoplasma hyopneumoniae infection in young pigs. Veterinary Microbiology, 49 (3-4), 297-303. doi:10.1016/0378-1135(95)00191-3

Vangroenweghe, F. A., Labarque, G. G., Piepers, S., Strutzberg-Minder, K., \& Maes, D. (2015). Mycoplasma hyopneumoniae infections in peri-weaned and post-weaned pigs in Belgium and The Netherlands: Prevalence and associations with climatic conditions. Veterinary Journal, 205 (1), 93-97. doi:10.1016/j.tvjl.2015.03.028

Vicca, J., Maes, D., Thermote, L., Peeters, J., Haesebrouck, F., \& de Kruif, A. (2002). Patterns of Mycoplasma hyopneumoniae infections in Belgian farrow-to-finish pig herds with diverging disease-course. Journal of Veterinary Medicine. B, Infectious Diseases and Veterinary Public Health, 49 (7), 349-353.

Vranckx, K., Maes, D., Calus, D., Villarreal, I., Pasmans, F., \& Haesebrouck, F. (2011). Multiple-locus variable-number tandem-repeat analysis is a suitable tool for differentiation of Mycoplasma hyopneumoniae strains without cultivation. Journal of Clinical Microbiology, 49 (5), 2020-2023. doi:10.1128/jcm.00125-11

Vranckx, K., Maes, D., Sacristan Rdel, P., Pasmans, F., \& Haesebrouck, F. (2012). A longitudinal study of the diversity and dynamics of Mycoplasma hyopneumoniae infections in pig herds. Veterinary Microbiology, 156 (3-4), 315-321. doi:10.1016/j.vetmic.2011.11.007

Wang, H., Feng, Z., Wu, Y., Wei, Y., Gan, Y., Hua, L., Shao, G. (2016). The effects of Mycoplasma hyopneumoniae on porcine circovirus type 2 replication in vitro PK-15 cells. Research in Veterinary Science, 105 , 56-61. doi:10.1016/j.rvsc.2016.01.015 
Weissenbacher-Lang, C., Kureljusic, B., Nedorost, N., Matula, B., Schiessl, W., Stixenberger, D., \& Weissenbock, H. (2016). Retrospective Analysis of Bacterial and Viral Co-Infections in Pneumocystis spp . Positive Lung Samples of Austrian Pigs with Pneumonia.Public Library of Science, 11 (7), e0158479. doi:10.1371/journal.pone.0158479

Wellenberg, G. J., Stockhofe-Zurwieden, N., Boersma, W. J. A., Jong, M. F., De, \& Elbers, A. R. W. (2004). The presence of co-infections in pigs with clinical signs of PMWS in The Netherlands: a case-control study. Research in Veterinary Science, 77 (2), 177-184.

Wills, R. W., Doster, A. R., Galeota, J. A., Sur, J. H., \& Osorio, F. A. (2003). Duration of infection and proportion of pigs persistently infected with porcine reproductive and respiratory syndrome virus. Journal of Clinical Microbiology, 41 (1), 58-62. doi:10.1128/jcm.41.1.58-62.2003

Wills, R. W., Zimmerman, J. J., Yoon, K. J., Swenson, S. L., McGinley, M. J., Hill, H. T., Nelson, E. A. (1997). Porcine reproductive and respiratory syndrome virus: a persistent infection. Veterinary Microbiology, 55 (1-4), 231-240. doi:10.1016/s0378-1135(96)01337-5

Yao, J., Qin, Y., Zeng, Y., Ouyang, K., Chen, Y., Huang, W., \& Wei, Z. (2019). Genetic analysis of porcine circovirus type 2 (PCV2) strains between 2002 and 2016 reveals PCV2 mutant predominating in porcine population in Guangxi, China. Bmc Veterinary Research, 15 (1), 118. doi:10.1186/s12917-019-1859-z

Yazawa, S., Okada, M., Ono, M., Fujii, S., Okuda, Y., Shibata, I., \& Kida, H. (2004). Experimental dual infection of pigs with an H1N1 swine influenza virus (A/Sw/Hok/2/81) and Mycoplasma hyopneumoniae .Veterinary Microbiology, 98 (3-4), 221-228. doi:10.1016/j.vetmic.2003.11.005

Zhang, H. R., Lunney, J. K., Baker, R. B., \& Opriessnig, T. (2011). Cytokine and chemokine mRNA expression profiles in tracheobronchial lymph nodes from pigs singularly infected or coinfected with porcine circovirus type 2 (PCV2) and Mycoplasma hyopneumoniae (MHYO). Veterinary Immunology and Immunopathology, 140 (1-2), 152-158. doi:10.1016/j.vetimm.2010.11.019

Zhang, N., Gao, P., Yin, B., Li, J., Wu, T., Kuang, Y., Li, J. (2019). Cathepsin L promotes secretory IgA response by participating in antigen presentation pathways during Mycoplasma Hyopneumoniae infection.Public Library of Science, 14 (4), e0215408. doi:10.1371/journal.pone.0215408

Zomborszky-Kovács, M., Kovács, F., Horn, P., Vetési, F., Repa, I., Tornyos, G., \& Tóth, Á. (2002). Investigations into the time- and dose-dependent effect of fumonisin B 1 in order to determine tolerable limit values in pigs. Livestock Production Science, 76 (3), 251-256.

\section{Table 1}

Main target sites for various swine pathogens in pig.

\begin{tabular}{llll}
\hline \multicolumn{1}{c}{ Pathogens } & Abbreviation & Target \\
\hline Viruses & Porcine Circovirus Type 2 & PCV2 & Lymphoid tissues \\
& Porcine Reproductive and Respiratory Syndrome Virus & PRRSV & Tonsil, upper respiratory tract and lun \\
& Swine Influenza Virus & SwIV & Epithelial cells of the upper respiratory \\
& Pseudorabies Virus & PRV & Mucosal epithelium, nervous system ti \\
Bacteria & Pasteurella multocida & PMULT & Lungs \\
& Actinobacillus pleuropneumoniae & APP & Tonsils, necrotic lung tissue and the na \\
& Lawsonia intracellularis & LI & Intestinal epithelial cells \\
\hline
\end{tabular}




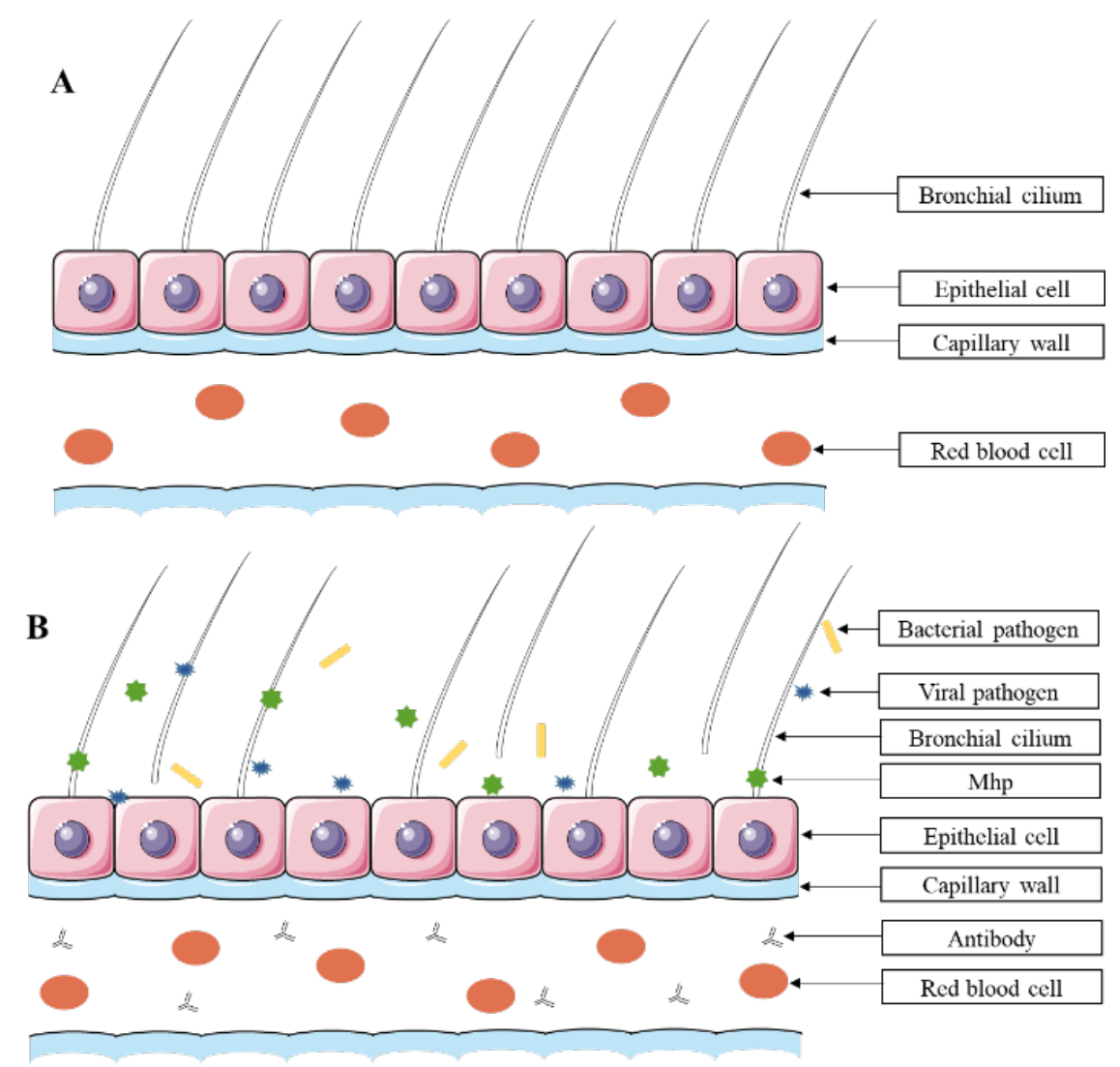

Fig. 1. The main process involved in the Mhp infection. (A) Mhp infection before. (B) Co-infection of Mhp and other swine pathogen. 


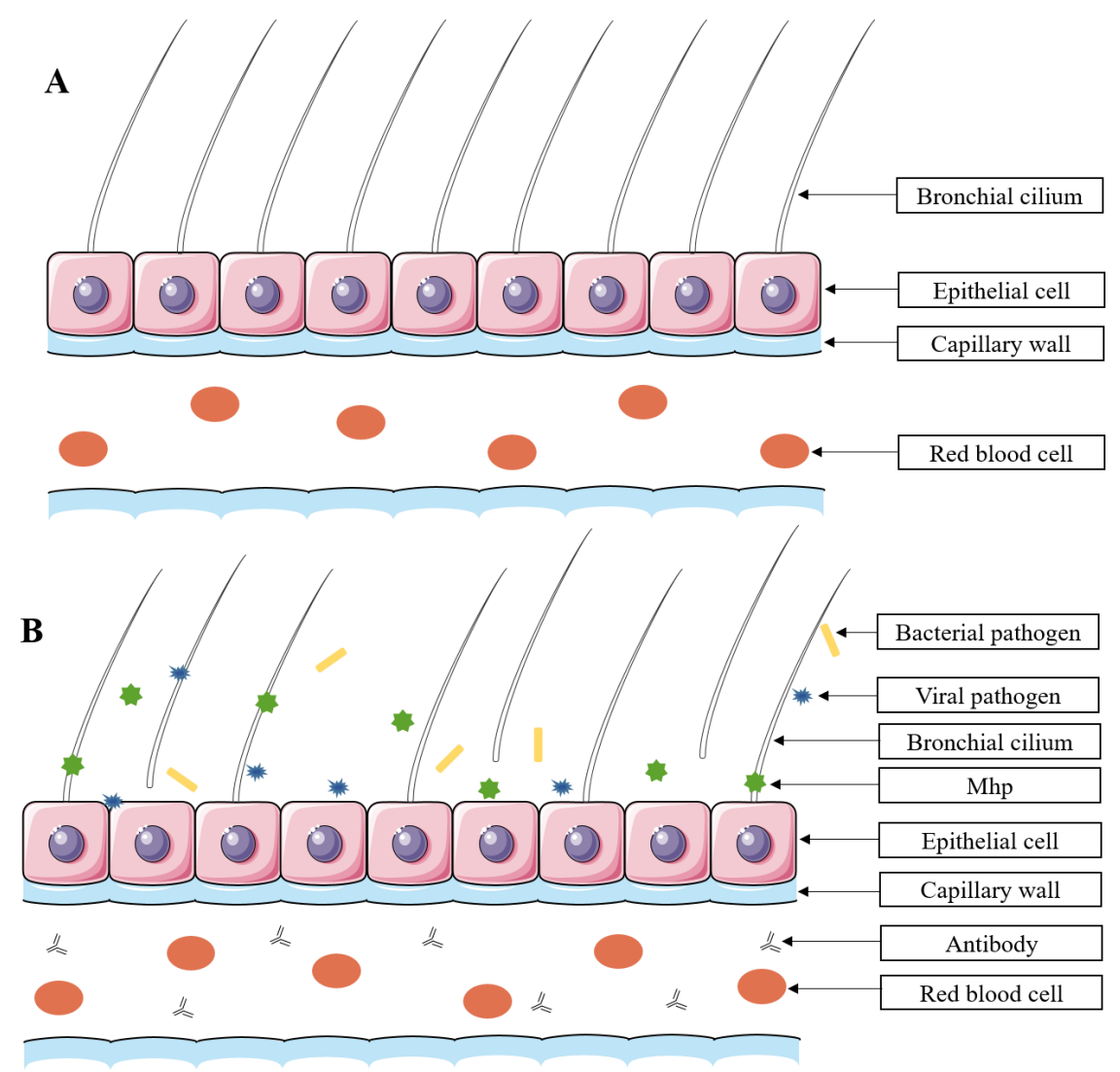

\section{Hosted file}

Table 1Main target sites for various swine pathogens in pig.docx available at https: //authorea.com/users/322723/articles/451679-co-infection-of-mycoplasma-hyopneumoniaeand-other-swine-pathogens 